\title{
Development Of Community-Based Tourism To Increase Regional Original Income (PAD) In Maros Regency
}

\author{
Irwan $^{1}$; Andi Agustang ${ }^{2}$; Adi Sumandiyar ${ }^{3}$ \\ 1,2,3 Mahasiswa S3 Ilmu Sosiologi Pascasarjana, Universitas Negeri Makassar \\ irwanunsa212@gmail.com
}

\begin{abstract}
This research to find out what is lacking and what should be done by the community around Rammang-Rammang tourism in Maros Regency in order to improve the quality of recreational tourism and increase local revenue. Thus, researchers want to conduct observations and research at the Rammang-Rammang Tourism Object with the title "Community Based Tourism Development to Increase Regional Original Income (PAD) in Maros Regency." Using descriptive research type which through qualitative research methods is to provide an overview of the problems studied related to the development of community-based tourism (Community Based Tourism). Based on the results of the research and discussion presented in the previous chapter on Community Based Tourism Development in Rammang-rammang Tourism, it can be concluded that natural and cultural resources are one of the main factors that attract tourists to visit, because There are typical foods of the Bugis and Makassar tribes, namely light snacks such as various kinds of cakes. From the Community Organizations in Rammang-Rammang Tourism, they still prioritize a sense of mutual cooperation between fellow residents to manage Rammang-Rammang tourism, because the Youth Organization in the village is still in the process of being formed. Management at Rammang-Rammang Tourism has no interference from any party, therefore the tourism management system is fully given to the community but is still under the supervision of the government. Meanwhile, learning is still in the construction stage of its facilities such as information boards, sign boards, landmarks, and location plans.
\end{abstract}

Keywords: Community Development, Locally-generated revenue, Tourism Development 


\section{Introduction}

Indonesian tourism is tourism that comes from, by and for the people, for that in planning tourism development it must involve the local (local) community, especially those around tourist destinations, because the local community is the owner and knows better about the destination (Ridwan, 2012).

The application of community-based tourism (CBT) is an approach to tourism development with participatory planning. or tourism businesses, so that profits are evenly distributed to communities in rural/coastal areas and small islands (Putra 2015).

Thus, CBT is an approach to tourism development that emphasizes the active role of local communities (both those who are directly involved in the tourism industry or not). This involvement is in the form of providing opportunities (access) in tourism management and development which leads to community empowerment, including in the sharing of profits from tourism activities (Putra, 2015). The form of critical attention is the idea of tourism development which often ignores the rights of local communities in tourist destinations (Hadiwijoyo, 2012).

Where the process of community involvement, both active and passive, must start from the planning stage to the management and development stage. This will foster responsibility and a sense of belonging that will determine the success and sustainability of tourism development. The considerable contribution of the tourism sector has caused the government to make the tourism sector a sector supporting national development and driving the people's economy.

It is hoped that the Maros Regency Government from its readiness, technical and management capabilities can make a positive contribution to the tourism sector. The limited capacity of human resources in the field of tourism management is a major issue in tourism development in Rammang-Rammang.

The Rammang-Rammang Tourism Village is able to provide a large multiplier effect. "The presence of this tourist village is expected to further increase opportunities for the community, providing a deep multiplier effect for the community. This is what we encourage, and I also instruct the ranks of the Ministry of Tourism and Creative Economy to provide assistance both in improving human 
resources, managing homestays, and others. In this case, according to Sandiaga, he will improve facilities in the area, ranging from electricity to waste management. Thus, the area deserves to be a UNESCO Global Geopark destination.

Therefore, based on the description of the background that has been described previously, it has become an attraction for holding this research, it is quite interesting to research and find out what is lacking and what the community around Rammang-Rammang tourism in Maros Regency should do in order to improve the quality of recreational tourism and increase local revenue. Thus, researchers want to conduct observations and research at the Rammang-Rammang Tourism Object with the title "Community Based Tourism Development to Increase Regional Original Income (PAD) in Maros Regency."

The purpose of this research is to describe the development of communitybased tourism (community based tourism) in order to increase Regional Original Income (PAD) in Maros Regency.

\section{Method}

This type of research is qualitative research. Using descriptive research type which through qualitative research methods is to provide an overview of the problems associated with the development of community-based tourism (Community Based Tourism).

Primary data researchers are data that the authors get directly from the source, namely the informants at the Rammang-Rammang Tourism Object and at the Maros Regency Tourism Office which are the objects of research. Secondary data is data obtained through the media to complement primary data obtained from the people who are in the Rammang-rammang Tourism Object and the staff at the Maros Regency Tourism Office such as books, articles, the internet or scientific journals that are related to the object being studied. investigated more accurately.

Determination of informants is done by purposive sampling, which means choosing directly informants who know more about the problem to be studied. Qualitative data analysis is carried out interactively and continues until it is 
complete, so that the data is saturated. These activities are data reduction, data presentation, and conclusion drawing.

\section{Result and Discussion}

The results of this study explain the development of tourism in Rammangrammang, Maros Regency which refers to the Community Based Tourism indicator (Community Based Tourism Development) Rocharungsat, 2008 in (Prabawati, 2013), namely the presence of Natural and Cultural Resources at the Rammangrammang Tourism Object. Empowerment is one of the triggers for increasing the economy of the local community, the existence of Community Organizations in assisting the government to develop tourism potential in Rammang-Rammang which is now being addressed and structured both from income and expenditure from the Rammang-Rammang Tourism Development phase and finally with the existence of Learning (learning) the visitors know a lot about Rammang-Rammang Tourism, especially the tourist locations.

\section{a. Development of Natural and Cultural Resources}

Natural and Cultural Resources here the meaning is how and what natural resources are found in Rammang-Rammang Tourism in increasing local revenue on the island and of course also with the presence of natural and cultural resources in the area, it is hoped that it can increase the interest of visiting tourists. who visited Maros Regency.

To find out the extent of tourism development in Rammang-rammang in the Natural and Cultural Resources sector, an interview was conducted with informant $\mathrm{AH}$, as a Community Leader around the Rammang-rammang Tourism Object who also understands the potential for tourism development as stated as follows: The development of the Rammang-Rammang Tourism Object has begun to be arranged slowly, accompanied by directions from the tourism office government to cultivate existing natural resources such as stone caves that lie long along the Rammang-Rammang tour. Besides that, we also have a culture here, which is typical Bugis Makassar, so if for example your sister or other visitors are 
hungry or want to eat snacks, there are many typical Bugis and Makassar cakes sold here such as Apang Cake, Barongko, Jalangkote, Pisang Ijo and various other cakes. " (Results of interview with informant AH, January 18, 2021).

Based on the results of several interviews above, it is clear that in order to increase Regional Original Income in the Rammang-Rammang Tourism Object through the Development of Community Based Tourism, it is necessary to pay more attention to the development of tourism potential in the Natural and Cultural Resources sector.

So with that the local community also feels the impact of the progress of Natural Resources and the community of course participates in contributing to the existence of Natural and Cultural Resources contained in the Rammang-rammang Tourism Object, Maros Regency. This is also in line with Murphy's theory of Community Based Tourism which focuses on natural and cultural resources

\section{b. Community Organization Development}

Community organizations referred to here are organizations formed either from local residents or from the relevant government. Community Organizations are here to accept the duties and responsibilities of the government to carry out several tasks of Community Based Tourism in Rammang-rammang so that the organizational structure continues to run well and in each field can control their respective duties. That way it can easily empower the people who live in the tourist attraction. To find out what the duties and functions look like

Community Organizations located in the Rammang-Rammang tourist attraction, the researchers conducted interviews with several related parties. The following is an interview with the researcher with the SF informant, namely the Tourism Destination Development Section at the Maros Regency Tourism Office: "When we talk about organizational issues, we from the government have also provided organizations or more to form organizations in which the majority of youth or millennials and there are also some members in it involve the community. Of course it really helps the government in maintaining the tourism potential in Maros Regency, one of which is Rammang-Rammang, therefore we formed a Tourism Awareness Group which is expected to be able to process and monitor 
properly this Rammang-Rammang Tourism Object and this group is supervised by itself. the government of Maros Regency." (Results of interviews with SF informants as the relevant Government, 18 February 2021).

These are the results of interviews with several informants related to the indicators in the researcher's research. Based on the results of the interviews above, the indicators of Community Organizations in the Rammang-Rammang Tourism Object are very necessary for the sake of. The community is also expected to increase their awareness in cooperating with each other in individual or group action. Even though a hospital informant said about the obstacles, it will soon be resolved with the formation of a Youth Organization for Youth Organizations whose selection process is directly elected by the community. So that way the more attention is paid to the sustainability and development of Community Based Tourism (Community Based Tourism) it can slowly increase Regional Original Income. This is also in line with Sunaryo's theory of Community Based Tourism which focuses on Community and Management.

\section{c. Tourism Management Development}

The management referred to here is how the Government involved in managing this Rammang-Rammang Tourism Object with its various tourism potentials, apart from the government through the community, we also get information on what forms of management and governance are, so that it can be well organized in order to facilitate access to Rammang. -rammang, so that visitors can easily find out the arrangement. The following are the results of interviews with researchers with several informants related to Management indicators and are more aware of these problems. Interviews with SF informants as the State Civil Apparatus (ASN) of the Maros Regency Tourism Office and the results of interviews with SF informants and researchers are as follows:

"If there are no regulatory issues from the government, it means that we do not provide such binding rules, so we give the local people freedom but we continue to monitor the development of the Rammang-Rammang Tourism Object, especially the Tourism Potential and Community Based Tourism. As for some of the appeals or directions that we have given from the government on how to keep 
the environment and beach clean from shipping and household waste." (Interview, March 18, 2021).

In line with the information provided by the Destination Development Section of the Maros Regency Tourism Office regarding economic improvement in the Rammang-Rammang Tourism Object, the RT informant as the Manager of Pasir Beach said the same thing. The following is an interview with RT informants:

"Right now, the Rammang-Rammang tour is being worked on for the construction of facilities such as Gasebo, and others. It's all still in the working stage and it is hoped that if everything is finished and finished it can be an added value for visitors so that they can make the Rammang-Rammang Tourism Object one of their list of tourist destinations. In addition to the beach facilities that are currently being worked on, there will also be a lanidmark or signboard.” (Interview, 20 March 2021).

Based on the results of several interviews above with the community and the government concerned, it is clear that the matter of Management at the Rammang-Rammang Tourism Object in empowering the community is clear which is relatively stable because from year to year development continues. In 2019, the government intervened with the local community to pay attention to tourism facilities such as Gasebo, Landmarks, and other supporting facilities that are still in the working stage in order to help increase Regional Original Income at the Rammang-rammang Tourism Object. This is also in line with Sunaryo's theory of Community Based Tourism which focuses on Community and Management

\section{d. Development of Learning}

The learning referred to here is that the object is more emphasized to Rammang-rammang Tourism Visitors, so that visitors can more easily understand and know about Rammang-rammang Tourism. In general, so that visitors can more easily find out the tourist locations they visit, there is a signboard that explains each existing facility or what icons are provided from the tourist spot. It would be better if there is a tour guide who accompanies the tourists who visit. That's what I want to know in Rammang-rammang Tourism, is there any application of such things regarding Learning. 
So the author conducted interviews with several related parties regarding the problem at Rammang-Rammang Tourism, thus the following are the results of interviews with $\mathrm{AH}$ informants as ASN regarding the problem of Learning (Learning) in Rammang-Rammang Tourism:

"For now, when it comes to learning, we government agencies have previously had a sign located at the entrance gate of Rammang-rammang Tourism. However, the signboard or location plan has been damaged and it is not possible to continue to display it, so we are from the government and directly from the Maros Regency Tourism Office to make Landmarks and Signs that are stored in every hallway and serve to direct the locations that tourists want to go to. All of them are entering the stage of the development process and the work process, you can see for yourself that on the beach there are already several gasebos that have been built which are made of brick, sand and the like". (Interview, March 18, 2019).

Likewise, the information that the researcher has also obtained from the informant AN as the Rammang-Rammang Tourism Manager regarding the problem of Learning (Learning) as in the previous interview. The following are the results of interviews with informants AN:

"We are very happy if there will be activities to be carried out at the Rammang-Rammang Tour, so that many participants from these activities will visit. If it is like that, we local people will feel a fairly large impact both from the increased income sector, in terms of knowledge we also increase. Why do I say in terms of knowledge, because if there is an activity that is held it will definitely involve the community and of course the community will get knowledge or something new which was previously unknown." (Interview, March 25, 2021).

Thus the results of interviews with informants related to the title of the research appointed by the researcher. In the process of collecting data and information in the Rammang-rammang Tourism area and the Maros Regency Tourism Office. In the process of collecting data and research at Rammangrammang Tourism and at the Tourism Office of Maros Regency, researchers discussed the basics in tourism development in Rammang-rammang Tourism: 
Natural and cultural resources, Community Organization, Management, and Learning (Learning).

First, the natural and cultural resources in Rammang-Rammang Tourism are the main factors that can easily attract tourism interest by local and foreign visitors, because the marine products on the island are very rich and diverse. Second, Community Organizations in Rammang-Rammang Tourism still rely on cooperation between neighbors to maintain the consistency of tourism in its management. The Community Organization under the auspices of the Village Head on the island is still in the process of forming the Village Level Youth Organization, so that the Village Head is very concerned about the formation of his youth group so that Rammang-Rammang Tourism can be managed better.

\section{Conclusion}

Based on the results of the research and discussion presented in the previous chapter on Community Based Tourism Development in Rammangrammang Tourism, it can be concluded that natural and cultural resources are one of the main factors that attract tourists to visit, because There are typical foods of the Bugis and Makassar tribes, namely light snacks such as various kinds of cakes. From the Community Organizations in Rammang-Rammang Tourism, they still prioritize a sense of mutual cooperation between fellow residents to manage Rammang-Rammang tourism, because the Youth Organization in the village is still in the process of being formed. Management at Rammang-Rammang Tourism has no interference from any party, therefore the tourism management system is fully given to the community but is still under the supervision of the government. Meanwhile, Learning / Learning is still in the construction stage of its facilities such as information boards, sign boards, landmarks, and location plans

\section{Reference}

Asker, S., Boronyak, L., Carrard, N., and Paddon, M., (2010). Effective Community Based Tourism, A Best Practice Manual. Singapore: Sustainable Tourism Cooperative Research. 
Devita, A., Delis, A., \& Junaidi, J. (2014). Pengaruh Pendapatan Asli Daerah, Dana Alokasi Umum dan Jumlah Penduduk terhadap Belanja Daerah Kabupaten/Kota di Provinsi Jambi. Jurnal Perspektif Pembiayaan dan Pembangunan Daerah, 2(2), 63-70.

Febriandhika, I., \& Kurniawan, T. (2019). Membingkai Konsep Pariwisata Yang Berkelanjutan Melalui Community-Based Tourism: Sebuah Review Literatur. JPSI (Journal of Public Sector Innovations), 3(2), 50-56.

Indraningrum, T., \& Rohman, A. (2011). Pengaruh Pendapatan Asli Daerah (PAD) dan Dana Alokasi Umum (DAU) Terhadap Belanja Langsung (Studi Pada Pemerintah Daerah Kabupaten/Kota Di Provinsi Jawa Tengah) (Doctoral dissertation, Universitas Diponegoro).

Muzha, V. K. (2013). Pengembangan agrowisata dengan pendekatan Community Based Tourism (Studi pada Dinas Pariwisata Kota Batu dan Kusuma Agrowisata Batu). Jurnal Administrasi Publik, 1(3), 135-141.

Nugroho, D. S. (2017). Community Based Tourism Tantangan Dusun Nglepen dalam Pengembangan Desa Wisata: Tinjauan Berdasarkan Teori Partisipasi Masyarakat.

Othman, Fadina, Sazali, Ferdhaus, \& Mohamed, Badaruddin. (2013). Rural and Community Based Tourism Development in Malaysia: Prospects for Homestays as a Social Economy Enterprise. TEAM Journal of Hospitality and Tourism, 10 (1): 65-76.

Pitana, I G. D, Surya. 2009. Pengantar Ilmu Pariwisata, Yogyakarta: CV Andi Offset.

Prabawati, Hemas Jakti Putri. 2013. Faktor- Faktor Keberhasilan Community Based Tourism Dalam Pengembangan Desa Wisata (Studi Kasus:PNPM Mandiri Pariwisata di Dataran Tinggi Dieng). Tugas Akhir Tidak Diterbitkan, Jurusan Perencanaan Wilayah dan Kota, Fakultas Teknik Universitas Diponegoro, Semarang.

Purbasari, N., \& Asnawi, A. (2014). Keberhasilan community based tourism di desa wisata Kembangarum, Pentingsari dan Nglanggeran. Teknik PWK (Perencanaan Wilayah Kota), 3(3), 476-485. 
Rizkianto, N. (2018). Penerapan Konsep Community Based Tourism dalam Pengelolaan Daya Tarik Wisata Berkelanjutan (Studi Pada Desa Wisata Bangun, Kecamatan Munjungan, Kabupaten Trenggalek). Jurnal Administrasi Bisnis, 58(1), 20-26.

Semiawan, C. R. (2010). Metode penelitian kualitatif. Grasindo.

Suansri, P., Yeejaw-haw, S., \& Richards, P. (2013). CBT standard handbook. Chiang Mai: The Thailand Community-Based Tourism Institute.

Sunaryo, B. (2013). Kebijakan Pembangunan Destinasi Pariwisata: Konsep dan Aplikasinya di Indonesia. Penerbit Gava Media.

Suasapha, A. H. (2016). Implementasi Konsep Pariwisata Berbasis Masyarakat dalam Pengelolaan Pantai Kedonganan. Jurnal Master Pariwisata (JUMPA).

Sugiyono. (2013). Metodologi Penelitian Kuantitatif, Kualitatif dan R\&D. Bandung: Alfabeta.

Sunaryo, B. (2013). Kebijakan Pembangunan Destinasi Pariwisata: Konsep dan Aplikasinya di Indonesia. Penerbit Gava Media. 